\title{
Life Cycle of the Eisenia fetida and Dendrobaena veneta Earthworms (Oligohaeta, Lumbricidae)
}

\section{Agnieszka Podolak1, Joanna Kostecka' , Anna Mazur-Pączka', Mariola Garczyńska', Grzegorz Pączka', Renata Szura'}

1 Department of the Basis of Agriculture and Waste Management, Institute of Agricultural Sciences, Land Management and Environmental Protection, College of Natural Sciences, University of Rzeszow, 1a Cwiklinskiej St., 35-601 Rzeszow, Poland

* Corresponding author's e-mail: apodolak@ur.edu.pl

\begin{abstract}
Earthworms can be used in the vermicomposting process. The success of the process depends on many factors, including the choice of the appropriate earthworm species. Eisenia fetida and Dendrobaena veneta are treated as "compost earthworms". They are characterized by a relatively short life cycle, relatively fast growth rate, efficient reproduction and a similar amount of organic matter processed, compared to species found in the natural environment. However, while analyzing their features in more detail, it can be seen that these two species differ. The aim of this study was to compare the selected features of the Eisenia fetida (Sav.) and Dendrobaena veneta (Rosa) earthworm populations in an annual cycle. The mature specimens of $E$. fetida or D. veneta were put in groups into plastic boxes with soil. Populations were checked regularly by manual sorting of the medium. The earthworms and cocoons were cleaned, counted and weighed individually. Afterwards, the mature individuals were placed in appropriate containers, while the cocoons were separated from the starting populations. The earthworms were fed ad libidum on kitchen wastes every four weeks. The experiment was carried out under constant laboratory conditions for 52 weeks. The analysis of the studied populations confirmed that the tested species of earthworms differ from each other. After 52 weeks of the experiment, the sum of earthworm biomass was higher for $D$. veneta compared to $E$. fetida species (18.568 $\pm 1.867 \mathrm{~g}$ and $7.263 \pm 1.786 \mathrm{~g}$; $\mathrm{p}<0.01$, respectively). This relationship was confirmed for the average body weight of earthworms (D. veneta: $0.912 \pm 0.046 \mathrm{~g} ;$ E. fetida $0.480 \pm$ $0.006 \mathrm{~g} ; \mathrm{t}=15.95, \mathrm{p}<0.01)$ and cocoons $($ D. veneta: $0.032 \pm 0.003 \mathrm{~g}$, E. fetida $0.014 \pm 0.001 \mathrm{~g} ; \mathrm{t}=9.15, \mathrm{p}<0.01)$.
\end{abstract}

Keywords: Eisenia fetida (Savigny 1826); Dendrobaena veneta (Rosa 1893); composting earthworm; annual cycle

\section{INTRODUCTION}

Earthworms have been used in vermicomposting for many years. This is an example of pro-environmental biotechnology enabling the processing of organic waste. It involves the decomposition of organic waste with the participation of a concentrated population of earthworms. This process can be controlled by people and its products are both vermicompost - a full-fledged fertilizer and the biomass of earthworm body (Kostecka, 2000; Sherman, 2003; Garg et al., 2005; Adi and Noor, 2009; Dominguez \& Edwards, 2011b; Adhikary, 2012; Bożym, 2012; Kostecka et al., 2018). The success of the vermicomposting process depends on many factors. Due to the fact that its effectiveness depends to a large extent, e.g. on the selection of the appropriate earthworm species, numerous studies are conducted around the world to compare and isolate the Lumbricidae species which are most suitable for this purpose (Bhattacharjee and Chaudhuri, 2002; Suthar, 2007; Dominguez and Edwards, 2011a; Adhikary, 2012; Lowe et al., 2014). The Eisenia fetida (Sav.) species is of particular interest, as it can be effectively used in the vermicomposting process due to the high reproduction rate and fast rate of organic waste processing. It is a species tested by many authors, both in terms of maintaining under laboratory conditions and in vermiculture. Dendrobaena veneta (Rosa) is a species relatively recently imported into anthropogenic environments, 
which is why this earthworm species has been the subject of many subsequent studies for some time. Both species can be found in vermiculture under the conditions of the Polish climate. Both earthworms called "compost" (Reinecke and Viljoen, 1990; Viljoen et al., 1991) are characterized by a relatively short life cycle, relatively fast growth rate, efficient reproduction and a similar amount of organic matter processed compared to the species found in the natural environment. However, while analyzing their features in more detail, it can be seen that these species differ from each other (Lofs-Holmin, 1985; Kasprzak, 1986; Dominguez and Edwards, 2011a). The previous studies showed the differences in sensitivity to anesthetics and chemical stress (Podolak et. al., 2019) and some features of the produced vermicompost (Kostecka et al., 2018).

In connection with the above, the aim of this study was to compare the selected features of Eisenia fetida (Sav.) and Dendrobaena veneta (Rosa) populations in an annual cycle.

\section{MATERIAL AND METHODS}

\section{Earthworms}

Composting earthworms, Eisenia fetida (Savigny, 1826) and Dendrobaena veneta (Rosa, 1893) (Annelida, Oligochaeta), derived from laboratory stocks at the Rzeszow University, were used for current experiment. The earthworm cultures were maintained under controlled laboratory conditions $\left(18 \pm 2^{\circ} \mathrm{C}, 24 \mathrm{~L}\right)$ in plastic boxes filled with culture medium and protected against moisture loss. The stock of earthworms was regularly fed ad libidum with organic household waste (according to resource).

\section{Culture medium - soil}

Horticultural substrate (Kronen Universalerde - universal soil) was used for the experiment, with the manufacturer's parameters of: $\mathrm{pH}\left(\mathrm{CaCl}_{2}\right) 5.5-6.5 ; \mathrm{N} \mathrm{200-450} \mathrm{mg/l}$; $\mathrm{P}_{2} \mathrm{O}_{5} 200-400 \mathrm{mg} / \mathrm{l} ; \mathrm{K}_{2} \mathrm{O} 300-500 \mathrm{mg} / \mathrm{l}$; ISO 9001 (2000).

\section{Experimental scheme}

Ten mature specimens (clitellate) of E. fetida $(0.480 \pm 0.007 \mathrm{~g})$ or D. veneta $(0.912 \pm 0.046)$ were put into plastic boxes $\left(10 \mathrm{dm}^{3}\right)$ with soil $\left(8 \mathrm{dm}^{3}\right)$ with proper humidity. Every four weeks, the populations were checked by manual segregation of the medium. The earthworms and cocoons selected from the soil were cleaned, counted and weighed individually. Afterwards, the mature individuals were placed in appropriate containers, while the cocoons were separated from the starting populations. The earthworms were fed $a d$ libidum every four weeks (pomace from apples, carrot and beetroot, cooked potatoes + cellulose in a ratio of 4:1). The experiment was carried out under constant laboratory conditions $\left(18 \pm 2^{\circ} \mathrm{C}\right.$, $24 \mathrm{~L}$ ) for 52 weeks. Three replicates were used for each experimental group.

\section{Statistical analyses}

STATISTICA v. 10 (StatSoft) was used for statistical analyses. The results were expressed as mean and standard deviations $(\overline{\mathrm{x}} \pm \mathrm{SD})$. In order to determine the significant differences in the mean number, weight and reproduction of the observed populations in the following time intervals, a one-way ANOVA method of variance analysis and multiple mean comparisons (NIR test) were used. When comparing the average values for two independent groups, the Student's t-test was used. $\alpha=0.05$ was established as the level of significance. The Spearman rank correlation coefficient was calculated to show the strength of the relationship between the selected parameters (Meisner, 2011; Stanisz, 2006; Łomnicki, 2007).

\section{RESULTS AND DISCUSSION}

\section{Earthworm number/ cocoon number}

The research showed that the population numbers of both earthworms species decreased during the 52 weeks of the experiment (Table 1). (E. fetida, $\mathrm{F}=2.31, \mathrm{p}<0.05 ;$ D. veneta, $\mathrm{F}=5.28$, $\mathrm{p}<0.001)$.

Other studies show that the average life expectancy of earthworms may depend on the species. Under favorable conditions, these animals can live up to 10 years (e.g. Lumbricus terrestris), although the average life expectancy is just over a year (Brzeski and Makulec, 1994). Rożen (2006) shows that the maximum life expectancy of the D. octaedra earthworms under laboratory conditions is 49 months. Edwards and Bohlen (1996) 
Table 1. Changes in the number of individuals E. fetida and D. veneta earthworm populations in an annual cycle (individual $\cdot$ container ${ }^{-1} \pm \mathrm{SD}$ )

\begin{tabular}{|c|c|c|c|c|c|c|c|c|c|c|c|c|c|c|c|}
\hline \multicolumn{2}{|c|}{ Week } & 0 & 4 & 8 & 12 & 16 & 20 & 24 & 28 & 32 & 36 & 40 & 44 & 48 & 52 \\
\hline \multirow{2}{*}{ 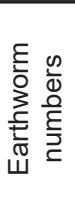 } & $\begin{array}{c}E . \\
\text { fetida }\end{array}$ & $\begin{array}{c}10.0 \\
\pm \\
0.0\end{array}$ & $\begin{array}{c}10.0 \\
\pm \\
0.0\end{array}$ & $\begin{array}{c}9.7 \\
\pm \\
0.6\end{array}$ & $\begin{array}{c}9.7 \\
\pm \\
0.6\end{array}$ & $\begin{array}{c}9.7 \\
\pm \\
0.6\end{array}$ & $\begin{array}{c}9.7 \\
\pm \\
0.6\end{array}$ & $\begin{array}{c}9.3 \\
\pm \\
0.6\end{array}$ & $\begin{array}{c}9.3 \\
\pm \\
0.6\end{array}$ & $\begin{array}{c}9.3 \\
\pm \\
0.6\end{array}$ & $\begin{array}{c}9.0 \\
\pm \\
0.0\end{array}$ & $\begin{array}{c}8.7 \\
\pm \\
0.6\end{array}$ & $\begin{array}{c}8.3 \\
\pm \\
1.2\end{array}$ & $\begin{array}{c}8.3 \\
\pm \\
1.2\end{array}$ & $\begin{array}{c}8.3 \\
\pm \\
1.2\end{array}$ \\
\hline & $\begin{array}{c}D . \\
\text { veneta }\end{array}$ & $\begin{array}{c}10.0 \\
\pm \\
0.0\end{array}$ & $\begin{array}{c}10.0 \\
\pm \\
0.0\end{array}$ & $\begin{array}{c}10.0 \\
\pm \\
0.0\end{array}$ & $\begin{array}{c}10.0 \\
\pm \\
0.0\end{array}$ & $\begin{array}{c}10.0 \\
\pm \\
0.0\end{array}$ & $\begin{array}{c}10.0 \\
\pm \\
0.0\end{array}$ & $\begin{array}{c}9.7 \\
\pm \\
0.6\end{array}$ & $\begin{array}{c}9.7 \\
\pm \\
0.6\end{array}$ & $\begin{array}{c}9.7 \\
\pm \\
0.6 \\
\end{array}$ & $\begin{array}{c}9.7 \\
\pm \\
0.6\end{array}$ & $\begin{array}{c}9.3 \\
\pm \\
0.6\end{array}$ & $\begin{array}{c}8.7 \\
\pm \\
0.6\end{array}$ & $\begin{array}{c}8.7 \\
\pm \\
0.6\end{array}$ & $\begin{array}{c}8.3 \\
\pm \\
0.6\end{array}$ \\
\hline
\end{tabular}

report that under laboratory conditions, E. fetida can survive 4.5 years. According to Lofs-Holmin (1985), mortality in the population of E. fetida under optimal conditions remains at $0-1 \%$ while for $D$. veneta it is $2 \%$. The current research allowed comparing the life expectancy of mature specimens of the studied species. In both cases, animal mortality during the study was $17 \%$, which may indicate their similar life expectancy under the conditions of the study. The mortality of individual earthworms during the experiment was accidental and did not depend on the species.

While analyzing the average number of cocoons found in experimental containers, it was found that this number fluctuated in subsequent weeks of the experiment (E. fetida, $\mathrm{F}=7.62$, $\mathrm{p}<0.001$; D. veneta, $\mathrm{F}=4.47, \mathrm{p}<0.001)$. It was observed that the earthworms of both species began to reproduce at the same time. Moreover, they deposited on average two cocoons per week per individual (Table 2). Other studies showed that juveniles appear faster in the earthworm population of E. fetida compared to D. veneta (Podolak et. al., 2019).

Other studies reported that the time necessary to start reproduction can be different even for the individuals of the same species, because it may depend, e.g. on the conditions in the culture. According to Górny (1975), the earthworm species found in litter and in surface soil layers are more exposed to temperature and humidity fluctuations, which is why they make more cocoons than the earthworms penetrating deeper soil layers. Brzeski and Makulec (1994), indicate that earthworms produce about $40-100$ cocoons per year. Larger species behave differently; living in deeper layers of soil, they produce about 5-27 cocoons per year. According to Lofs-Holmin (1985), the E. fetida earthworms reach maturity after about 30 days and begin laying cocoons. In the case of the $D$. veneta earthworms, the maturation process is usually longer, so that the first cocoons appear in populations after about 40 days. Dominguez and Edwards (2011a) report that this time for E. fetida is about 28-30 days, but for $D$. veneta, it is longer and extended to 65 days. In the present research, the mature specimens were introduced into the experiment, and therefore began to form their cocoons at about the same time.

During the conducted research, it was found that both earthworm species deposited on average about 2 cocoons per week per individual. Other authors (Brzeski and Makulec 1994) report that at the same time as presented in the study, these earthworms can lay up to five cocoons. Similar results are presented by Lofs-Holmin (1985) claiming that $E$. fetida produce on average 6 cocoons per week, whereas in $D$. veneta it is about 5 cocoons. On the basis of the obtained data, it cannot be clearly stated which population produced more cocoons, because relatively large values of standard deviations made it impossible to compare the average number of cocoons deposited by both tested species (Table 2). The number of cocoons may also depend on the type of food supplied. Kostecka (2000) shows that the E. fetida earthworms deposited an average of $1.7 \pm 1.4$ cocoons per week, but the addition of cellulose to

Table 2. Changes in the number of cocoons laid by $E$. fetida or $D$. veneta individual (cocoon $\cdot$ mature individual $^{-1}$ $\pm \mathrm{SD})$ in an annual cycle

\begin{tabular}{|c|c|c|c|c|c|c|c|c|c|c|c|c|c|c|c|c|}
\hline \multicolumn{2}{|c|}{ Week } & 0 & 4 & 8 & 12 & 16 & 20 & 24 & 28 & 32 & 36 & 40 & 44 & 48 & 52 & Mean \\
\hline \multirow{2}{*}{ 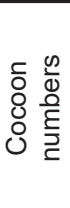 } & $\begin{array}{c}E . \\
\text { fetida }\end{array}$ & $\begin{array}{l}0 \\
\pm \\
0\end{array}$ & $\begin{array}{l}7 \\
\pm \\
0\end{array}$ & $\begin{array}{l}6 \\
\pm \\
1\end{array}$ & $\begin{array}{l}9 \\
\pm \\
1\end{array}$ & $\begin{array}{l}9 \\
\pm \\
1\end{array}$ & $\begin{array}{c}10 \\
\pm \\
1\end{array}$ & $\begin{array}{l}8 \\
\pm \\
1\end{array}$ & $\begin{array}{l}11 \\
\pm \\
1\end{array}$ & $\begin{array}{l}9 \\
\pm \\
2\end{array}$ & $\begin{array}{c}12 \\
\pm \\
1\end{array}$ & $\begin{array}{l}9 \\
\pm \\
2\end{array}$ & $\begin{array}{l}7 \\
\pm \\
2\end{array}$ & $\begin{array}{l}8 \\
\pm \\
1\end{array}$ & $\begin{array}{l}8 \\
\pm \\
1\end{array}$ & $\begin{array}{c}8.6 \text { a } \\
\pm \\
2.0\end{array}$ \\
\hline & $\begin{array}{c}D . \\
\text { veneta }\end{array}$ & $\begin{array}{l}0 \\
\pm \\
0\end{array}$ & $\begin{array}{l}6 \\
\pm \\
0\end{array}$ & $\begin{array}{l}7 \\
\pm \\
0\end{array}$ & $\begin{array}{l}7 \\
\pm \\
1\end{array}$ & $\begin{array}{l}7 \\
\pm \\
1\end{array}$ & $\begin{array}{c}10 \\
\pm \\
1\end{array}$ & $\begin{array}{l}8 \\
\pm \\
1\end{array}$ & $\begin{array}{l}9 \\
\pm \\
0\end{array}$ & $\begin{array}{l}7 \\
\pm \\
1\end{array}$ & $\begin{array}{l}8 \\
\pm \\
1\end{array}$ & $\begin{array}{c}12 \\
\pm \\
2\end{array}$ & $\begin{array}{c}10 \\
\pm \\
2\end{array}$ & $\begin{array}{l}8 \\
\pm \\
1\end{array}$ & $\begin{array}{l}8 \\
\pm \\
0\end{array}$ & $\begin{array}{c}8.2 \mathrm{a} \\
\pm \\
1.8\end{array}$ \\
\hline
\end{tabular}


the culture medium increased both their number and weight. In the present research, a similar set of waste was used as food and results similar to those presented by the author were obtained.

According to Górny (1975), the earthworm species found in litter and in surface soil layers are more exposed to temperature and humidity fluctuations, which is why they make more cocoons than the earthworms penetrating deeper soil layers. According to Brzeski and Makulec (1994), the former lay about 40-100 cocoons per year. Larger species behave differently; living in deeper soil layers, they produce about 5-27 cocoons per year. Dominguez and Edwards (2004) report that E. fetida can produce $0.35-1.3$ cocoons per day, and $D$. veneta 0.28 cocoons during the day, on average.

\section{Body weight/ cocoon weight}

The obtained data show a regular increase in the biomass of both populations till 32 weeks of the experiment. The total biomass of the population of E. fetida earthworms was lower than the average total biomass of the $D$. veneta earthworm population after 52 weeks $(7.263 \pm 1.786 \mathrm{~g}$ and $18.568 \pm 1.867 \mathrm{~g}$, respectively) $(\mathrm{t}=7.58$, $\mathrm{p}<0.01)$. The average body weight of mature E. fetida after 52 weeks reached more than half of the average body weight of $D$. veneta $(0.480$ $\pm 0.006 \mathrm{~g}$ and $0.912 \pm 0.046 \mathrm{~g}$, respectively) $(\mathrm{t}=$ 15.95, $\mathrm{p}<0.01$ ) (Fig. 1).

According to the available publications, the compared species are similar to each other, but E. fetida is an earthworm with smaller body sizes; therefore, it achieves a lower average individual weight than D. veneta (Lofs-Holmin 1985). Mature body weights correlate with the data obtained by Dominguez and Edwards (2011a) where the average weight of mature individual E. fetida was $0.55 \mathrm{~g}$, and D. veneta was $0.92 \mathrm{~g}$.

The body weight of earthworms, as well as the reproduction rate largely depend on the type of food supplied (Sangwan et al., 2008). For example, in the experiment of Garg et al., (2005) the highest mass was reached for the E. fetida earthworms processing the sheep manure, and the lowest for the individuals feeding on the horse manure. In other studies (Kostecka, 2000), it was shown that after a year breeding, the body weight of mature E. fetida earthworms reached $0.764 \pm 0.447 \mathrm{~g}$. In the conducted research, earthworms regularly received the kitchen waste containing boiled potatoes. Additionally, a large living space and lack of density (caused by the removal of cocoons) of animals influenced the value of the obtained body mass.

The earthworms of different species lay cocoons of different shape and size (Kasprzak, 1986, Edwards and Bohlen, 1996, Dominguez and Edwards, 2011a). The current research has confirmed that this is a characteristic feature of each species. The E. fetida cocoons were smaller compared to the $D$. veneta cocoons (Fig. 2).

While analyzing the average masses of cocoons from $E$. fetida and $D$. veneta populations, they were found irregular in subsequent weeks of the experiment (Fig. 3) (E. fetida, $\mathrm{F}=1.78$, $\mathrm{p}>0.05, D$. veneta, $\mathrm{F}=5.88, \mathrm{p}<0.01)$. Nevertheless, the cocoons laid by E. fetida earthworm were lighter compared to the cocoons laid by $D$. veneta

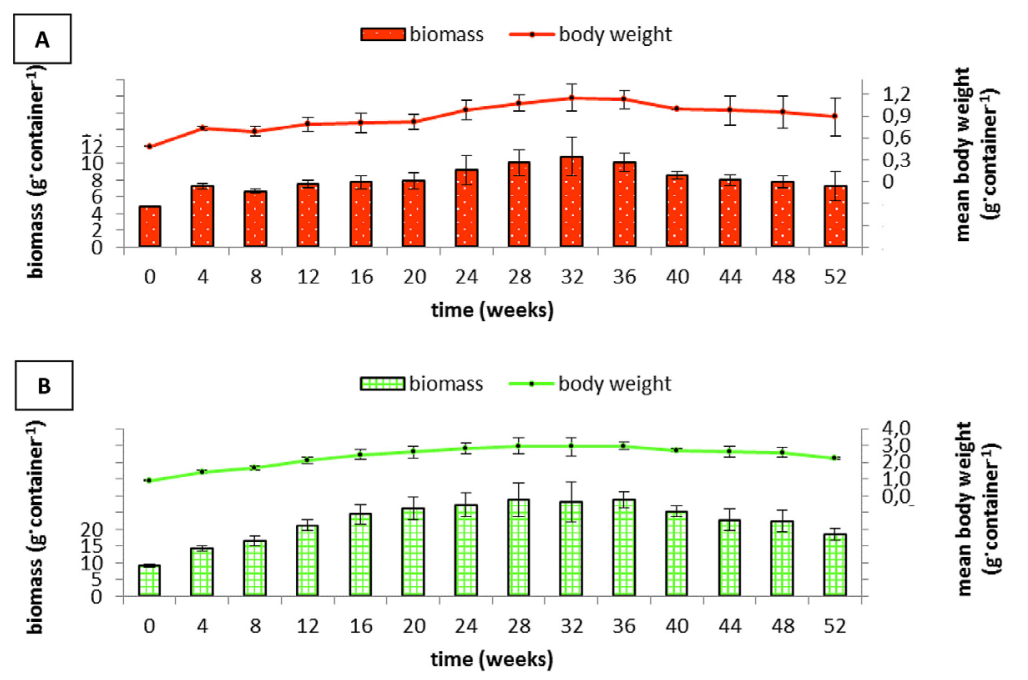

Fig. 1. Changes in biomass of population $\left(\mathrm{g} \cdot\right.$ container $\left.^{-1} \pm \mathrm{SD}\right)$ and mean body weight $\left(\mathrm{g} \cdot\right.$ individual $^{-1}$ $\pm \mathrm{SD}$ ) of mature individuals: A) E. fetida, B) D. veneta earthworm in an annual cycle 

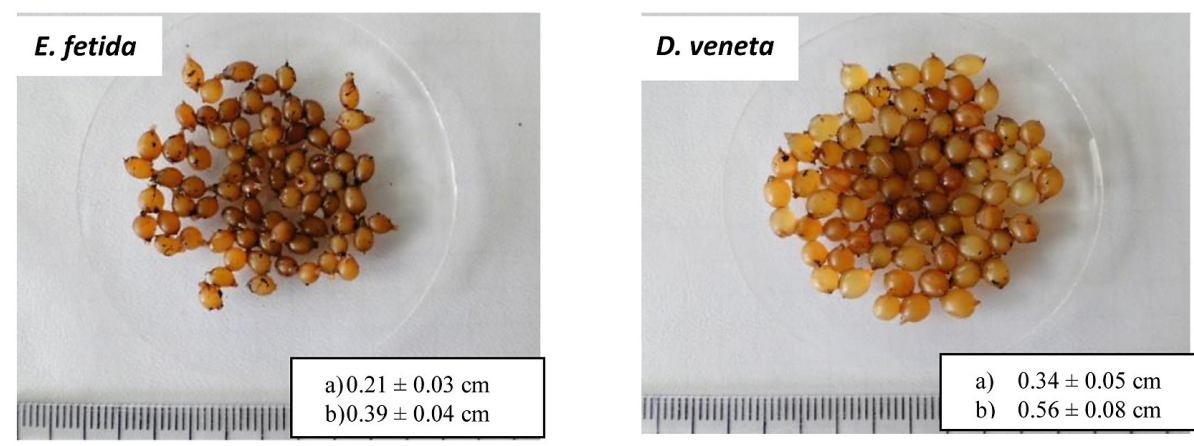

Fig. 2. Cocoons of E. fetida and D. veneta earthworms ( $\mathrm{a}$ - width, $\mathrm{b}-$ length; $\overline{\mathrm{X}} \pm \mathrm{SD}, \mathrm{n}=50$ )
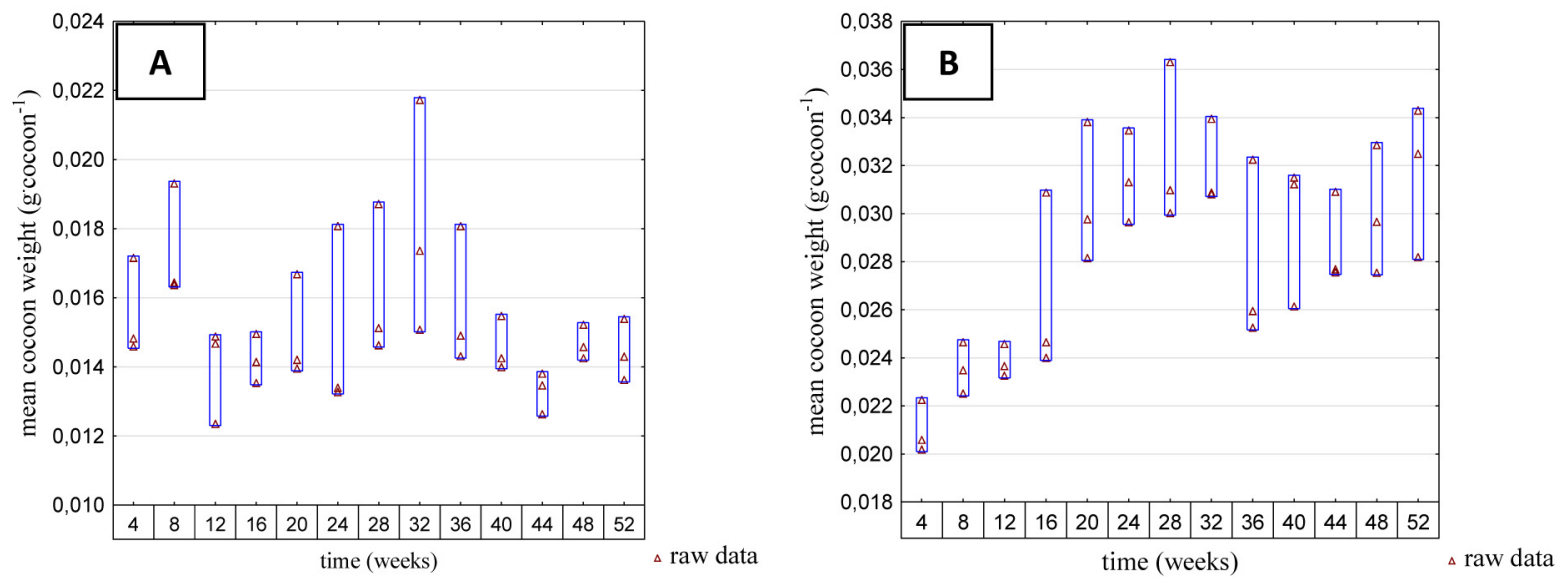

Fig. 3. Change of mean cocoon weight $\left(\mathrm{g} \cdot \operatorname{cocoon}^{-1}\right)$ of A) E. fetida or B) D. veneta earthworms in an annual cycle

$(0.014 \pm 0.001 \mathrm{~g} ; 0.032 \pm 0.003 \mathrm{~g}$, respectively $\mathrm{t}=9.15, \mathrm{p}<0.01)$.

While analyzing the relationship between the average body weight of breeding individuals and the average mass of laid cocoons in the E. feti$d a$ populations, no such relationship was found $(\mathrm{rs}=0.209, \mathrm{p}>0.05)$. Positive moderate correlations of average body weight of mature individuals and the average cocoon weight were found in the population of $D$. veneta earthworms ( $\mathrm{rs}=$ $0.659, \mathrm{p}<0.05)$. This means that with the growth of the body weight of mature individuals, the mass of a single cocoon increases as well.

\section{CONCLUSIONS}

While analyzing the selected features of the studied populations, it was confirmed that the tested species of earthworms differ from each other. After 52 weeks of the experiment, the sum of earthworm biomass was higher for $D$. veneta compared to the E. fetida species (18.568 \pm $1.867 \mathrm{~g}, 7.263 \pm 1.786 \mathrm{~g} ; \mathrm{p}<0.01$, respectively). This relationship was confirmed for the average body weight characteristic of both species of earthworms (D. veneta: $0.912 \pm 0.046 \mathrm{~g} ;$ E. fetida $0.480 \pm 0.006 \mathrm{~g} ; \mathrm{t}=15.95, \mathrm{p}<0.01)$. The $D$. veneta earthworm cocoons were larger, which also confirms the interspecies differences $(D$. veneta: $0.032 \pm 0.003 \mathrm{~g}$, E. fetida $0.014 \pm 0.001 \mathrm{~g}$; $\mathrm{t}=9.15, \mathrm{p}<0.01)$.

\section{REFERENCES}

1. Adhikary S. 2012. Vermicompost, the story of organic gold: A review. Agricultural Sciences, 3 (7), 905-917.

2. Adi A.J., Noor Z.M. 2009. Waste recycling: Utilization of coffee grounds and kitchen waste in vermicomposting. Bioresource Technology, 100, 1027-1030.

3. Bhattacharjee G., Chaudhuri P.S. 2002. Cocoon production, morphology, hatching pattern and fecundity in seven tropical earthworm species - a laboratory-based investigation. Journal of Biosciences, 27, 283-294.

4. Bożym M. 2012. Biologiczne przetwarzanie biodegradowalnej frakcji odpadów komunalnych i osadów ściekowych w wermikulturze. Prace 
Instytutu Ceramiki i Materiałów Budowlanych, 10, 335-349 (in Polish)

5. Brzeski M.W., Makulec G. 1994. Dżdżownice. Ich produkty w ogrodach, działkach i w tunelach. Wydawnictwo Host. Gdańsk, 1-20 (in Polish).

6. Dominguez J., Edwards C.A. 2004. Vermicomposting organic wastes: A review. In: Soil Zoology for Sustainable Development in the 21st Century. (Eds.) Shakir Hanna S.H., Mikhall W.Z.A. Cairo, 369-395.

7. Dominguez J., Edwards C.A. 2011a. Biology and Ecology of Earthworm Species used for Vermicomposting. In: Vermiculture technology. Earthworms, organic wastes and environmental management. (Eds.) Edwards C.A., Arancon N.Q., Shreman R. CRC. Taylor and Francis Group. Press. Boca Raton. London, New York, 3, 27-40.

8. Dominguez J., Edwards C.A. 2011b. Relationships between Composting and Vermicomposting. In: Vermiculture technology. Earthworms, organic wastes and environmental management. (Eds.) Edwards C.A., Arancon N.Q., Shreman R. CRC. Taylor and Francis Group. Press. Boca Raton. London, New York, 2, 11-25.

9. Edwards, C.A., Bohlen, P.J. 1996. Biology and Ecology of Earthworms. Chapman and Hall. London, New York, Melbourne, Madras, ss. 426.

10. Garg V.K. Chand S., Chhillar A., Yadav A. 2005. Growth and reproduction of Eisenia foetida in various animal wastes during vermicomposting. Applied Ecology and Environmental Research, 3, 51-59.

11. Górny M. 1975. Zooekologia gleb leśnych. Państwowe Wydawnictwo Rolnicze i Leśne. Warszawa, ss. 310 (in Polish).

12. Kasprzak K. 1986. Skąposzczety glebowe III, dżdżownice (Lumbricidae). PAN Instytut Zoologii. Klucz do oznaczania bezkręgowców Polski. Wydawnictwo Naukowe PWN. Warszawa, ss. 187 (in Polish).

13. Kostecka J. 2000. Badania nad wermikompostowaniem odpadów organicznych. Zeszyty Naukowe AR w Krakowie. Rozprawy, 268, 1-88 (in Polish).

14. Kostecka J., Garczyńska M., Podolak A., Pączka G., Kaniuczak J. 2018. Kitchen organic waste as material for vermiculture and source of nutrients for plants. Journal of Ecological Engineering, 19(6), 267-274.

15. Lofs-Holmin A. 1985. Vermiculture - Present knowledge of the art of earthworm farming - a summary of recent literature. Sveriges lantbruksuniversitet. Uppsala, 1-69
16. Łomnicki A. 2007. Wprowadzenie do statystyki dla przyrodników. Wydawnictwo Naukowe PWN. Warszawa, ss. 260 (in Polish).

17. Lowe Ch.N., Butt K.R., Sherman R.L. 2014. Current and Potential Benefits of Mass Earthworm Culture. In: Mass Production of Beneficial Organisms. Invertebrates and Entomopathogens. (Eds.) Morales-Ramos J., Rojas G., Shapiro-Ilan D.I. Academic Press of Elsevier, 683-709.

18. Meisner W. 2011. Przewodnik do ćwiczeń z przedmiotu metody statystyczne w biologii. Wydawnictwo Uniwersytetu Gdańskiego. Gdańsk, ss. 131 (in Polish).

19. Podolak A., Kostecka J., Rożen A., Garczyńska M., Pączka G., Mazur-Pączka A., Szura R. 2019. New perspectives for the use of earthworms - testing of anesthetics. Journal of Ecological Engineering, 20(3), 253-261.

20. Podolak A., Kostecka J., Garczyńska M., Pączka G., Mazur-Pączka A., Szura R. 2019. Influence of stress factor on E. fetida and D. veneta earthworm populations (in press).

21. Reinecke A.J., Viljoen S.A. 1990. The influence of worm density on growth and cocoon production of the compost worm Eisenia fetida (Oligochaeta). Rev. Ecol. Biol. Sol, 27, 221-230.

22. Rożen A. 2006. Effect of cadmium on life-history parameters in Dendrobaena octaedra (Lumbricidae: Oligochaeta) populations originating from forests differently polluted with heavy metals. Soil Biology and Biochemistry, 38, 489-503.

23. Sangwan P., Kaushik C.P., Garg V.K. 2008. Feasibility of utylization of horse dung spiked filter cake in vermicomposters using exotic earthworm Eisenia foetida. Bioresource Technology, 99, 2442-2448.

24. Sherman R. 2003. Raising earthworms successfully. North Carolina Cooperative Extension Service. North Carolina State University, Raleigh, NC, 1-26.

25. Stanisz A. 2006. Przystępny kurs statystyki z zastosowaniem STATISTICA PL na przykładach $z$ medycyny, tom 1 Statystyki podstawowe. StatSoft Polska. Kraków, ss. 532 (in Polish).

26. Suthar S. 2007. Vermicomposting potential of Perionyx sansibaricus (Perrier) in different waste materials. Bioresource Technology, 98, 1231-1237.

27. Viljoen S.A., Reinecke A.J., Hartman L. 1991. Lifecycle of the European compost worm Dendrobaena veneta (Oligochaeta). South African Journal of Zoology, 26, 43-48. 